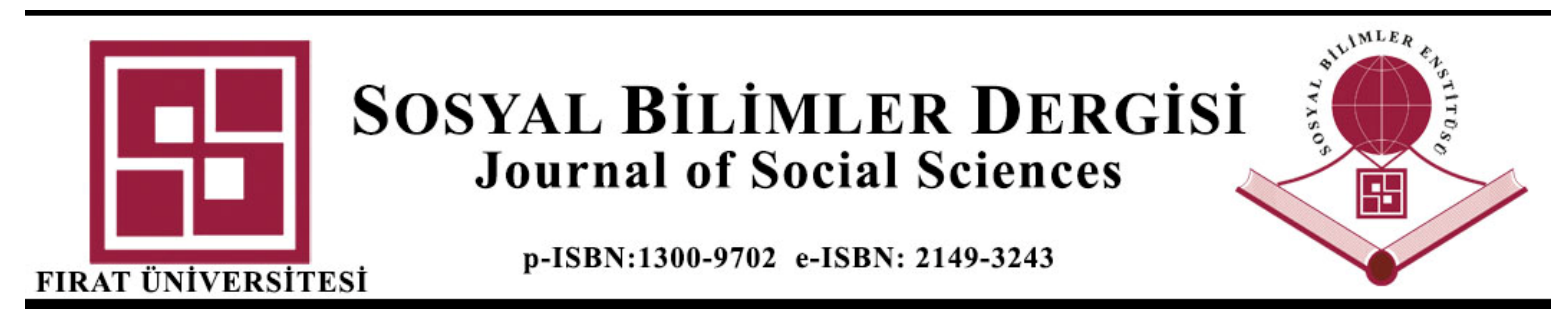

\title{
COMPARISON OF ETHICAL, TRANSFORMATIONAL, PATERNALISTIC, SPIRITUAL AND INSTRUCTIONAL LEADERSHIP STYLES
}

\section{Etik, Dönüşümcü, Paternalist, Spiritüel ve Öğretimsel Liderlik Stillerinin Karşılaştırılması}

\author{
Mustafa ÖZGENEL ${ }^{1}$, Baran Barış YILDIZ ${ }^{2}$, Pınar MERT ${ }^{3}$ ve İsmail Eray DURSUN ${ }^{4}$ \\ ${ }^{l}$ Doç. Dr. Ístanbul Sabahattin Zaim Üniversitesi, Eğitim Fakültesi, Eğitim Bilimleri Bölümü, İstanbul, \\ mustafa.ozgenel@izu.edu.tr,orcid.org/0000-0002-7276-4865 \\ ${ }^{2}$ Dr. Avcılar İlçe Milli Eğitim Müdürlügü̈, Istanbul, bbaris_yildiz@windowslive.com, orcid.org/0000-0001-6186-4038 \\ ${ }^{3}$ Dr. Öğr. Üyesi, İstanbul Sabahattin Zaim Üniversitesi, Eğitim Fakültesi, Eğitim Bilimleri Bölümü, İstanbul, \\ pinar.mert@izu.edu.tr,orcid/0000-0003-3633-7556 \\ ${ }^{4}$ Bakırköy İlçe Milli Eğitim Müdürlüğ̈̈, İstanbul, ismail.eray.dursun@gmail.com, orcid.org/0000-0002-6420-7487
}

Araștırma Makalesi/Research Article

Makale Bilgisi
Geliş/Received:
21.03.2021
Kabul/Accepted:
13.09.2021
DOI:
10.18069/firatsbed.900510

Keywords

Leadership,

transformational

leadership, ethical

leadership, paternalistic

leadership, instructional

leadership, spiritual

leadership ABSTRACT
In this study, it is aimed to compare the ethical, transformational, paternalistic, spiritual, and
instructional leadership styles of school principals. For this purpose, the research has been
carried out according to the survey model. 586 teachers from Istanbul province participated in
the study. A high level of a positive correlation has been found between the leadership styles
of school administrators perceived by the teachers. Teachers most perceived ethical leadership
style and least perceived paternalist leadership style of school administrators. While teachers'
perceptions of instructional, transformational, ethical, and spiritual leadership styles differ
significantly according to their gender; It does not differ significantly according to their
educational status. It has been determined that the instructional, transformational, ethical,
paternalist, and spiritual leadership styles of school administrators differ significantly
according to the type, grade, and age variables. The instructional, transformational, paternalist
and spiritual leadership styles of school principals do not differ significantly according to the
seniority variable; however, it has been determined that the ethical leadership style of school
administrators differed significantly according to the seniority variable. It has been determined
that instructional, transformational, ethical, paternalist, and spiritual leadership styles of
school administrators differ significantly; according to the type of schools, grade, and age
variables.
Anahtar Kelimeler

Liderlik, Etik liderlik,

dönüşümcü liderlik,

paternaslit liderlik, ruhsal

liderlik, öğretimsel liderlik

\section{ÖZ}

$\mathrm{Bu}$ araştırmada okul müdürlerinin etik, dönüşümcü, babacan/paternalist, ruhsal/spiritüel ve öğretimsel liderlik stillerinin karşılaştırılması amaçlanmıştır. $\mathrm{Bu}$ amaç doğrultusunda araştırma betimsel tarama desenine göre gerçekleştirilmiştir. Araştırmaya İstanbul ilinden 586 öğretmen katılmıştır. Okul müdürlerinin öğretmenler tarafından algılanan liderlik stilleri arasında pozitif yönde yüksek düzeyde anlamlı ilişki tespit edilirken; öğretmenler okul müdürlerinin en fazla etik liderlik stilini en az ise paternalist liderlik stilini sergilediğini düşünmektedir. Öğretmenlerin öğretimsel, dönüşümcü, etik ve ruhsal liderlik stilleri algıları cinsiyetlerine göre anlam farklılık gösterirken; eğitim durumlarına göre anlamlı farklılık göstermemektedir. Öğretmenlerin görev yaptıkları okul/kurum türüne/kademesine ve yaşlarına göre okul müdürlerinin öğretimsel, dönüşümcü, etik, paternalist ve ruhsal liderlik stilleri anlamlı farklılık gösterdiği tespit edilmiştir. Okul müdürlerinin öğretimsel, dönüşümcü, paternalist ve ruhsal liderlik stilleri öğretmenlerin kıdemlerine göre anlamlı farklılık göstermediği; ancak okul müdürlerinin etik liderlik stili öğretmenlerin kıdemlerine göre anlamlı farkl1lık gösterdiği belirlenmiştir.

Atıf/Citation: Özgenel, M., Yıldı, B. B., Mert, P., Dursun. İ. E. (2021). Comparison of Ethical, Transformational,

Paternalistic, Spiritual and Instructional Leadership Styles, Firat Üniversitesi Sosyal Bilimler Dergisi, 31, 3(1191-1209). 


\section{Introduction}

Increasing radical changes are taking place in the world, and the changes in social life and technology for many years can be seen even in less than a day in the present century (Can, 2002). Factors such as developments in the digital society, changes in the social environment structure, change of population balance, changing education and economic policies, and foreign relations of the country affect organizations directly or indirectly. As a result of these effects, old management approaches leave their place to new approaches and ideas. These rapid changes also force educational organizations to change, direct them to new searches, and increase the efforts of the organizations (Özdemir, 2000). In this respect, the importance of education leaders is realized more. Education leaders need to take advantage of the opportunities provided by the change to draw new paths to the organization and make the organization defensible against external threats. Because of this reason, educational organizations have to reorganize and evaluate their organizational identities and leadership styles. In the modern era of sudden changes, educational organizations, like other organizations, need new leadership approaches that strengthen their management skills (Altınkurt, 2007). According to House et al. (2004), Turkey is a people-oriented, high power distance, and collectivist country. However, it is known that Turkish school administrators are mostly male, have teacher-centered education and teach a teacher-centered education, and do not have education in informatics and technology (Gumus and Akcaoglu). Besides, the school administration hasn't seen as a profession, but as an additional task to the teaching profession (Balc1, 2002).

On the other hand, it has stated in the literature that school leadership plays a key role in school reform (Bryk, Sebring, Allensworth, Luppescu, \& Easton, 2010; Hallinger \& Heck, 1998; Leithwood, Louis, Anderson, \& Wahlstrom, 2004; Supovitz, Sirinides, \& May 2010; Waters, Marzano \& McNulty, 2003). While studying what kind of characteristics, character, and behaviors education leaders should have, it should not be ignored that each leadership style has different benefits and risks within its own dynamics. In this study, important leadership styles in the field of education such as paternalist, ethical, transformational spiritual, and instructional, which are seen as different from each other, but complementary to each other in general or have arisen in opposition to each other, have been discussed and compared.

\subsection{Paternalist Leadership}

Paternalist leadership is a more collective leadership style with a high power distance, feudal structure (Aycan, Schyns, Sun, Felfe, \& Saher, 2013; Pellegrini \& Scandura, 2008). Paternalist leadership has been affected by the cultural values of the society that it occurs. While Asian-type paternalist leadership has been influenced by Confucian philosophy, Turkish-type paternalist leadership has been influenced by Ottoman culture and Islamic values (Cheng et al., 2014; Song, 2016).

Paternalist leaders behave like a family member and show great interest in important events of their followers such as funerals, weddings, and diseases (Karakitapoğlu-Aygün, Gumusluoglu, \& Scandura, 2013), build good relationships, and help them cope with their problems (Rego et al., 2012). On the other hand, discipline and authority are important in paternal leadership (Aycan, 2006; Cheng, Chou, Wu, Huang, \& Farh, 2004). There are two models of the dimensions of patriarchal leadership. According to Cheng et al. (2004), it has three dimensions: authoritarianism, benevolence, and moral leadership. However, Aycan (2006) tried to clarify the concepts and especially distinguished benevolent paternalism and exploitative paternalism. In this research, Cheng et al. (2004) have been focused on the dimensions it creates. The caring paternalist leader protects subordinates and deals with their problems at work or in personal life.

On the other hand, paternalist leaders always make them feel the strong authority attitudes about who the boss is (Cheng et al., 2004). The moral paternalist leader, on the other hand, obeys the rules accepted by the society and is shown as an exemplary role model by the environment. Also uses authority and power not only for personal benefits but also for the benefit of society (Westwood, 1997). The authoritarian paternalist leader has a lofty image. 
Since the authoritarian paternalist leader does not know the abilities of his followers, he decreases their motivation (Karakitapoğlu-Aygün, Gumusluoglu, \& Scandura, 2013). When the research findings in the literature are examined, it is observed that the philanthropic paternalist leader has a positive effect on the performances of the followers, the authoritarian and self-interested paternalist leadership dimensions are not effective and affected negatively (Chan, Huang, Snape, \& Lam, 2013; Chan \& Mak, 2012; Chen, Eberly, Chiang, Farh \& Cheng, 2014; Mert \& Özgenel, 2020; Wu, Huang, Li, \& Liu, 2011). According to Özgenel and Canuylası, (2021) the paternalist leader generally supports school happiness and affects the bureaucratic school culture in a positive way (Özgenel \& Dursun, 2020).

\subsection{Ethical Leadership}

Ethical norms in organizations are determined by ethical leaders. Klaus M. Leisinger states that "income" in an organization has the same meaning as nutrition which is a necessity for people. Just as nutrition is not the only meaning of a person's life, earning is not the only purpose of an organization. Although the prestige of an organization is not included in its balance sheet, it is one of the most important components of the organization (Tepe, 2000). It has seen that ethical values such as respectability should be among the important components in addition to earnings for the organization, as an important task of ethical leadership. Brown et al. (2005, p. 120) define ethical leadership as "showing normative appropriate behavior through personal action and interpersonal relationships and introducing such behaviors to followers through two-way communication, empowerment and decision making". Ethical leaders act both for the well-being and development of the society and for the psychological well-being and satisfaction of their employees (Avey, Wernsing, \& Palanski, 2012; Treviño, Brown, \& Hartman, 2003). Ethical leaders trust the rules. Ethical leaders also take decisions based on ethical principles and are firmly committed to all aspects of moral management. It is claimed that ethical leadership includes features of all previous ethical leadership styles (Van Wart, 2014).

As proof of this, it has been revealed in researches that ethical leadership has positive results for teachers (Cohen et al., 2009; Eyal et al., 2011; Greenlee \& Brown, 2009). Having ethical leaders increases pride and loyalty to the organization and strengthens feelings of moral commitment (Philipp \& Lopez, 2013). In addition, ethical leadership affected organizational citizenship behavior (Philipp \& Lopez, 2013; Toor \& Ofori, 2009; Treviño et al., 2003), organizational health (Özgenel \& Aksu, 2020), organizational opposition (Özgenel, Baydar, \& Baydar, 2019), employees' emotional and their normative commitment (Den Hartog \& De Hoogh, 2008; Kim \& Brymer, 2011), teachers' normative commitment to the school and the school climate positively (Özgenel \& Yayık, 2019).

\subsection{Transformational Leadership}

In 1978 Burns in his book called "Leadership"; defines political leadership by dividing it into two; behavioral and transformative. In this book, he laid the foundation of, transformational leadership bases on the leader and the audience's aim to achieve high goals in order to mutually increase each other's motivation and meet their high-level needs. Later, Bass has transformed transactional leadership into transformational leadership in his studies since 1985, based on Burns (Bryman, 1992). Through their high ethical behavior and intellectually deep visions, transformational leaders provide inspiration to employees to act by taking into account their needs and guide them to look at existing problems from a new perspective (Kwan, 2019). Therefore, transformational leadership has some sub-dimensions: idealized effect, inspiring motivation, intellectual stimulation, and individualized evaluation (Avolio \& Bass, 1991; Avolio, Bass, \& Jung, 1999). Idealized impact indicates that the norms, characteristics, and behaviors of the leader are accepted at the ideal level by the audience and thus the desire to identify with the leader spirational motivation refers to; the leader's role model, creating an engaging vision and encouraging the audience to reach this goal, push the limits, and take risks. Intellectual stimulation shows how much a leader can encourage his followers to be more reformist and more creative. 
Individual interest means that the leader can take into account the needs of each audience individually and contribute to their development (Bass, 1999). According to Breevaart et al. (2014), transformational leaders are more effective leaders than leaders who adopt transactional approaches. It has been reported that transformational leaders increase individual performance among employees, individual creativity, team performance, and organizational performance (Wang et al., 2011), and job satisfaction (Erktulu, 2008), besides affect organizational trust and citizenship behavior (Podsakoff et al., 1990), improve work resources, (Albrecht et al., 2015), strengthen participation (Ghadi, Fernando \& Caputi, 2013; Hayati et al., 2014; Tims et al., 2011; Hawkes, Biggs, \& Hegerty, 2017), and develop creative and innovative solutions to problems (Bass and Bass, 2008), create a shared vision, takes risks, appreciates employees and attaches importance to teamwork (Özgenel \& Karsantik, 2020), positively influences staff empowerment (Jung, Chow, \& Wu, 2003; Parker \& Griffin, 2011), It has been reported that it negatively affects organizational cynicism (Özgenel \& Hıdıroğlu, 2019).

\subsection{Spiritual Leadership}

It is difficult for a leader who cannot understand his own spirit to understand the spirit of the organization due to the spirit of his employees. In this sense, today organizations move away from the bureaucratic structure and adopt human-oriented management (Baloğlu \& Karadağ, 2009; Karadağ, Altınay Aksal, Altınay Gazi \& Dağli, 2020) and also value-based leadership styles that attach importance to spiritual intelligence have gained importance (Özgan et al. ., 2013).Leadership styles based on these values are; ethical leadership (Starratt 2005; Stefkovich \& Begley 2007), spiritual leadership (Woods 2007), and poetic leadership (Deal 2005). The spiritual leader creates a common vision desired by employees (Hoppock, 1935), inspires employees (Fry, 2003), and gives them the hope of reaching their dreams in the workplace by increasing their job satisfaction (Weng, Huang, Chen, \& Chang, 2015).

Fundamentally, spiritual leadership includes authenticity, intentionality, spirituality, and sensitivity (Bhindi \& Duignan, 1997). According to Egel and Fry (2017), a spiritual leader makes employees feel that their worklife has a meaning, creates common values (Akıncı \& Ekşi, 2017; Fairholm, 1996), creates school culture (Karadağ et al., 2020; Özgenel \& Ankaralıoğlu, 2020). They trust employees, motivate them to trust each other, and indeed they are internally motivated (Fry et al., 2005; Law, 2008; Mitroff \& Denton, 1999; Özgan et al., 2013).

Spiritual leaders those increase the life satisfaction and organizational commitment of followers (Fry \& Slocum, 2008; Salehzadeh et al., 2015) alson improve their followers' organizational citizenship behaviors (Chen et al., 2013; Chen \& Yang, 2012; Pio \& Tampi, 2018; Kalkan et al., 2020; Koç \& Başaş, 2019), besides arise their productivity (Bozkuş \& Gündüz, 2015; DePree, 1992), their performance (Akıncı \& Ekşi, 2017; Koç \& Baştaş, 2019; Krishnakumar et al., 2015), their level of commitment (Malone \& Fry, 2003), job satisfaction (Abdullah et al., 2009), and the academic success of the school as a whole (Koç \& Bastas, 2019; Koçyiğit, 2017; Malone \& Fry, 2003).

\subsection{Instructional Leadership}

Studies on leadership in the field of education have focused on transformational and instructional leadership styles, and it has been discussed which leadership style is more effective than the other one. Gümüş, Bellibaş, Esen, and Gümüş (2016) stated that instructional leadership dominated the field from 1980 to 1995, but transformational leadership came to the fore in the mid-1990s, and again in the last decade, instructional leadership started to become effective again in order to increase the effectiveness of schools.

Robinson, Lloyd, and Rowe (2008) underlined that the effect of instructional leadership on student outcomes is at least three times greater than transformational leadership. According to Hallinger and Murphy (1985), instructional leadership includes three groups of leadership activities. These are; defining the school mission (framing clear school goals and transmitting clear goals), managing teaching programs (supervising and evaluating teaching, coordinating curriculum, and monitoring student progress), and creating a positive school 
climate (maintaining teaching time, promoting professional development, providing high visibility providing opportunities for teachers to learn). As an instructional leader (King, 2002), the school administrator who is responsible for all educational issues and student achievement should share these responsibilities with teachers (Glickman, 1989; Marks \& Printy, 2003) and work together with teachers to improve the quality of the curriculum, education, teaching, and learning (Marks \& Printy).,2003). In this sense, the relationship between school administrators and teachers is very important (Gümüş \& Akçaoğlu, 2013). Because the school administrator as an instructional leader will need the collaboration of teachers to achieve the goals set before. Instructional leader improves teachers' professional commitment and innovation levels (Sheppard, 1996), increase teacher productivity (Duyar, Gümüş, \& Bellibas, 2013; Ross \& Gray, 2006; Tschannen-Moran \& Woolfolk Hoy, 2007), and student success (Krug, 1992).

In summary, research shows that school leaders have a significant influence on student achievement (Bush, 2009; Supovitz et al., 2010). The main purpose of this study is to determine the extent to which school administrators' leadership behaviors perceived moreby teachers who work in public schools in Turkey. In accordance with this purpose; (i) Is there a significant relationship between school principals' leadership styles perceived by teachers? (ii) Is there a significant relationship between school principals' leadership styles perceived by teachers and the school levels where teachers work? (ii) Do school principals 'leadership styles perceived by teachers differ significantly according to the teachers' gender, educational status, the school level they strike, their ages, seniority, and the time they worked with the current principal? answers were sought. Although there are many studies on different leadership styles or behaviors, the strength of this study is the comparison of five different leaders (paternalist, ethical, transformational spiritual, and instructional).

\section{Methodology}

\subsection{Research Model}

In this study, since it was aimed to compare the paternalist, ethical, transformational, spiritual and instructional leadership styles of school principals perceived by teachers, the research was designed and conducted according to the quantitative research method and survey model. The main purpose of the survey model is to define the features of the universe (Fraenkel, Wallen, \& Hyun, 2012). In other words, the survey model is used to determine the opinions, feelings, attitudes, tendencies, or perceptions of people in a very large group (population) about an event, situation, subject, or phenomenon through a smaller group (sample) through the scale / s-questionnaire. It is a quantitative research model conducted in order to collect and generalize this information to the universe.

\subsection{Study Group}

The study group of the research consists of 586 teachers who are selected by the method of "convenience sampling" among the teachers working in public schools in the Anatolian Side of Istanbul.The "convenience sampling method was used because of the COVID-19 epidemic that occurred during the period of the study. The "convenience sampling" sampling method is a method, in which the sample can easily accessible and select from applicable units due to the limitations in terms of time, money and labor " (Büyüköztürk, 2012). $65.7 \%$ (385) of the teachers are female and $34.3 \%$ (201) are male in the study. While $86.3 \%$ of the teachers have undergraduate degree, $13.7 \%$ have graduate degree and $37.7 \%(220)$ of the teachers work in kindergarten and primary school, $19.6 \%$ (115) in secondary school, 36.2\% (212) in high school and 6.7\% (39) work in public education and science and art centers.

\subsection{Data Collection Tools}

Permission was obtained from the researchers, the researchers who developed the scales and the Istanbul Sabahattin Zaim University Ethics Committee (Ethics Committee decision dated 27.11.2020 and numbered 2020/11). The data collection tool contains a personal information form. Instructional Leadership Scale, 
Managerial Spiritual Leadership Perception Scale, Paternalist Leadership Behaviors Scale, Ethical Leadership Scale and Transformational Leadership Scale have been used to obtain data in the study.

Instructional Leadership Scale (ILS); was developed by Alig-Meilcarek (2003) and adapted to Turkish by Şahin (2011). The scale consists of 3 dimensions and 23 items. The items in the scale are rated as a 5-point Likert-type scale, "completely agree (5), agree (4), partially agree (3), disagree (2), absolutely disagree (1)". 23 as lowest and 115 as highest point can be taken from the Instructional Leadership Scale.

The Transformational Leadership Scale (TLS) was developed by Akan, Yıldırım, and Yalçın (2014). The scale is consists of one-dimension and 20 items. The scale is rated as a 5-point Likert type as "I totally agree (5), agree (4), partially agree (3), disagree (2), strongly disagree (1)". 20 as lowest and 100 as highest point can be taken from the Transformational Leadership Scale.

Ethical Leadership Scale (ELS) was developed by Brown, Trevino, and Harrison (2005) and adapted into Turkish by Muharrem, Bircan, and Yeşiltaş (2012). ELS, which consists of 10 items and one dimension, is a 5-point Likert type scale that is answered and scored as "I totally agree (5), I agree (4), I partially agree (3), I do not agree (2), I strongly disagree (1)". 10 as lowest and 50 as highest point can be taken from the Ethical Leadership Scale.

Managerial Spiritual Leadership Perception Scale (SLS) was developed by Akıncı and Ekşi (2017). The scale consists of 28 items and four sub-dimensions named "Hope/belief, Interpretation, Efficiency and Vision". The scale is rated as a 5-point Likert type scale as "I totally agree (5), agree (4), partially agree (3), disagree (2), strongly disagree (1)". The lowest score of 28 and the highest score of 140 can be taken from the Spiritual Leadership Scale.

The Paternalist Leadership Behaviors Scale (PLS) was developed by Dağlı and Ağalday (2017). The scale consists of 22 items and four sub-dimensions (benevolent leadership, moral leadership, self-interested leadership, authoritarian leadership). The scale was rated as a 5-point Likert type scale as "I totally agree (5), agree (4), partially agree (3), disagree (2), strongly disagree (1)". 22 as lowest and 110 as highest point can be taken from the Paternalist Leadership Scale.

\subsection{Data Analysis}

Before the data was analyzed, kurtosis and skewness values had been calculated and it had been examined that the data had shown a normal distribution. Besides, the Cronbach Alpha reliability coefficient of the scales was calculated and given in Table 1.

Table 1. Kurtosis, Skewness and Reliability Values of the Scales

\begin{tabular}{lcccc}
\hline & $\mathrm{N}$ & Kurtosis & Skewness & Cronbach Alpha \\
\hline 1- Instructional Leadership & 586 & -.168 & -.364 & .966 \\
2-Transformational Leadership & 586 & -.472 & -.363 & .978 \\
3-Ethical Leadership & 586 & -.428 & -.307 & .947 \\
4- Paternalist Leadership & 586 & .101 & .141 & .752 \\
5-Spiritual Leadership & 586 & -.404 & -.183 & .973 \\
\hline
\end{tabular}

When Table 1 is examined, it is seen that the kurtosis values of the scales varied between .478 and .101 , and the skewness values varied between -.364 and .141 , and it is decided that the data shows a normal distribution. It is understood that the reliability coefficients ranged between .752 and .978 and the scales are reliable. The arithmetic mean values of the scales are evaluated according to the given criteria: $1.00-1.79=$ very low; 1.80 $2.59=$ low; $2.60-3.39=$ medium; 3.40-4.19 = high; $4.20-5.00=$ very high.

\section{Findings}

The relationship among the instructional, transformational, ethical, paternalist, and spiritual leadership styles of school administrators perceived by teachers, the relationship among these leadership styles and the school levels teachers work in are presented in Table 2. 
Comparison of Ethical, Transformational, Paternalistic, Spiritual and Instructional Leadership Styles

Table 2. Results of Correlation Analysis Regarding Leadership Styles

\begin{tabular}{|c|c|c|c|c|c|c|c|}
\hline & Mean & sd & 1 & 2 & 3 & 4 & 5 \\
\hline 1-Instructional Leadership & 3.80 & .643 & 1 & & & & \\
\hline 2-Transformational & 3.93 & .759 & $.887 * *$ & 1 & & & \\
\hline 3- Ethical Leadership & 3.97 & .709 & $.872 * *$ & $.884 * *$ & 1 & & \\
\hline 4- Paternalist Leadership & 3.48 & .344 & $.699 * *$ & $.693 * *$ & $.692 * *$ & 1 & \\
\hline 5- Spiritual Leadership & 3.92 & .664 & $.882 * *$ & $.918 * *$ & $.911 * *$ & $.738 * *$ & \\
\hline 6-School level & & & $-.193 * *$ & $-.214 * *$ & $-.166^{* *}$ & $-.129 * *$ & $-.175 * *$ \\
\hline
\end{tabular}

According to Table 2, teachers perceive all leadership styles of school principals at a "high" level. Considering the arithmetic averages of leadership styles, from highest to lowest; ethical leadership style $(\mathrm{M}=3.97$; $\mathrm{sd}=$ .709), transformational leadership style $(\mathrm{M}=3.93 ; \mathrm{sd}=.759)$, spiritual leadership style $(\mathrm{M}=3.92 ; \mathrm{sd}=.664)$, instructional leadership style $(\mathrm{M}=3.80 ; \mathrm{sd}=.643)$ and paternalist leadership style $(\mathrm{M}=3.48 ; \mathrm{sd}=.344)$.

According to Table 2, it is determined that there are positive and highly significant relationships among the instructional, transformational, ethical, paternalist, and spiritual leadership styles of school administrators according to the perceptions of the teachers $(\mathrm{p}<.01)$. The highest relationship between leadership styles is among transformational leadership style and spiritual leadership style $(\mathrm{r}=.918 ; \mathrm{p}<.01)$; the lowest correlation is determined to be between paternalist leadership style and ethical leadership style $(r=.692 ; p<.01)$. Finally, there is a negative relationship between leadership styles and school levels, though at a low level. In other words, as the school grade continues from kindergarten-primary to middle school and high school, the leadership styles of school administrators decrease in a negative way.

In order to determine whether the instructional, transformational, ethical, paternalistic and spiritual leadership styles of school administrators differ significantly according to the gender of the perceiver teachers, the independent samples t-test results are given in Table 3.

Table 3. T-test Results of Teachers' Perceptions of Instructional, Transformational, Ethical, Paternalist and Spiritual Leadership Styles of School Administrators According to Gender Variable

\begin{tabular}{|c|c|c|c|c|c|c|c|}
\hline Variables & Samples & $\mathbf{N}$ & $\mathbf{M}$ & SD & $\mathbf{t}$ & df & $\mathbf{p}$ \\
\hline \multirow{2}{*}{$\begin{array}{l}\text { Instructional } \\
\text { Leadership }\end{array}$} & Female & 385 & 3,7584 & ,62856 & \multirow{2}{*}{$-2,286$} & \multirow{2}{*}{584} & \multirow{2}{*}{, 023} \\
\hline & Male & 201 & 3,8860 & 66464 & & & \\
\hline \multirow{2}{*}{$\begin{array}{l}\text { Transformational } \\
\text { leadership }\end{array}$} & Female & 385 & 3,8787 & ,74567 & \multirow{2}{*}{$-2,498$} & \multirow{2}{*}{584} & \multirow{2}{*}{, 013} \\
\hline & Male & 201 & 4,0430 & ,77524 & & & \\
\hline \multirow{2}{*}{ Ethical Leadership } & Female & 385 & 3,9270 & ,67303 & \multirow{2}{*}{$-2,492$} & \multirow{2}{*}{584} & \multirow{2}{*}{,013 } \\
\hline & Male & 201 & 4,0801 & ,76498 & & & \\
\hline \multirow{2}{*}{$\begin{array}{l}\text { Paternalist } \\
\text { Leadership }\end{array}$} & Female & 385 & 3,4747 & ,32859 & \multirow{2}{*}{$-1,267$} & \multirow{2}{*}{584} & \multirow{2}{*}{,206 } \\
\hline & Male & 201 & 3,5126 &, 37175 & & & \\
\hline \multirow{2}{*}{$\begin{array}{l}\text { Spiritual } \\
\text { Leadeership }\end{array}$} & Female & 385 & 3,8702 & ,63213 & \multirow{2}{*}{$-2,673$} & \multirow{2}{*}{584} & \multirow{2}{*}{,008 } \\
\hline & Male & 201 & 4,0240 &, 71352 & & & \\
\hline
\end{tabular}

When Table 3 is examined, male teachers' perceptions of leadership styles, instructional $\left(\mathrm{t}_{[584]}=-2.286 ; \mathrm{p}<.05\right)$, transformational $\left(\mathrm{t}_{[584]}=-2.498 ; \mathrm{p}<.05\right)$, ethical $\left(\mathrm{t}_{[584]}=-2.492 ; \mathrm{p}<.05\right)$ and spiritual $\left(\mathrm{t}_{[584]}=-2.673 ; \mathrm{p}<.05\right)$, significantly different and higher than female teachers. However, it is seen that there is no significant difference between male and female teachers' perceptions of the paternalist leadership style of school administrators ( $p>.05)$. In other words, it is determined that male and female teachers 'perceptions of school administrators' paternalist leadership style are similar.

Independent samples t-test results are presented in Table 4 to determine whether the instructional, transformational, ethical, paternalist, and spiritual leadership styles of school administrators differ significantly according to the teachers' educational status variable. 
Table 4. Comparison of the Instructional, Transformational, Ethical, Paternalist, and Spiritual Leadership Styles of School Administrators According to the Teaches' Educational Status Variable

\begin{tabular}{|c|c|c|c|c|c|c|c|}
\hline Variables & Groups & $\mathbf{N}$ & M & SD & $\mathbf{t}$ & df & $\mathbf{p}$ \\
\hline \multirow{2}{*}{$\begin{array}{l}\text { Instructional } \\
\text { Leadership }\end{array}$} & Undergraduate & 506 & 3,8183 & ,63522 & \multirow{2}{*}{1,522} & \multirow{2}{*}{584} & \multirow{2}{*}{, 128} \\
\hline & Postgraduate & 80 & 3,7005 & 68884, & & & \\
\hline \multirow{2}{*}{$\begin{array}{l}\text { Transformational } \\
\text { leadership }\end{array}$} & Undergraduate & 506 & 3,9505 & ,76075 & \multirow{2}{*}{1,237} & \multirow{2}{*}{584} & \multirow{2}{*}{,216 } \\
\hline & Postgraduate & 80 & 3,8375 & ,74742 & & & \\
\hline \multirow{2}{*}{$\begin{array}{l}\text { Ethical } \\
\text { Leadership }\end{array}$} & Undergraduate & 506 & 3,9992 & ,70495 & \multirow{2}{*}{1,693} & \multirow{2}{*}{584} & \multirow{2}{*}{,091 } \\
\hline & Postgraduate & 80 & 3,8550 &, 72634 & & & \\
\hline \multirow{2}{*}{$\begin{array}{l}\text { Paternalist } \\
\text { Leadership }\end{array}$} & Undergraduate & 506 & 3,4940 & ,34622 & \multirow{2}{*}{1,115} & \multirow{2}{*}{584} & \multirow{2}{*}{,265 } \\
\hline & Postgraduate & 80 & 3,4478 & ,33013 & & & \\
\hline \multirow{2}{*}{$\begin{array}{l}\text { Spiritual } \\
\text { Leadership }\end{array}$} & Undergraduate & 506 & 3,9363 & ,66887 & \multirow{2}{*}{1,219} & \multirow{2}{*}{584} & \multirow{2}{*}{, 223} \\
\hline & Postgraduate & 80 & 3,8388 & 63449 & & & \\
\hline
\end{tabular}

When Table 4 is examined, teachers' perceptions of instructional $\left(\mathrm{t}_{[584]}=1.522 ; \mathrm{p}>.05\right)$, transformational $\left(\mathrm{t}_{[584]}=1.237 ; \mathrm{p}>.05\right)$, ethical $\left(\mathrm{t}_{[584]}=1.693 ; \mathrm{p}>.05\right)$, paternalist $\left(\mathrm{t}_{[584]}=1.115 ; \mathrm{p}>.05\right)$ and spiritual $\left(\mathrm{t}_{[584]}=1.219\right.$; $\mathrm{p}>.05)$ styles differ significantly according to their education levels.

The results of One-Way ANOVA analysis conducted to determine whether the teachers' perceptions of instructional, transformational, ethical, paternalist, and spiritual leadership styles of school administrators differ significantly according to the type of school/institution they work in (Table 5).

Table 5. ANOVA Results of Teachers' Perceptions of Instructional, Transformational, Ethical, Paternalist, and Spiritual Leadership Styles of School Administrators According to School Type Variable

\begin{tabular}{|c|c|c|c|c|c|c|c|c|c|c|c|}
\hline & School & $\mathbf{N}$ & M & SD & $\begin{array}{l}\text { Source of } \\
\text { Variance }\end{array}$ & $\begin{array}{l}\text { Sum of } \\
\text { Squares }\end{array}$ & df & $\begin{array}{l}\text { Mean } \\
\text { square }\end{array}$ & $\mathbf{F}$ & p & Sig. \\
\hline \multirow{5}{*}{ 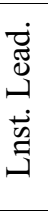 } & A-K/PS & 220 & 3,949 & 0,553 & Bet. Gr. & 10,638 & 3 & 3,546 & \multirow{5}{*}{8,912} & \multirow{5}{*}{, 000} & \multirow{5}{*}{$\begin{array}{l}\mathbf{A}>\mathbf{C} ; \\
\mathbf{B}>\mathbf{C}\end{array}$} \\
\hline & B-Ss & 115 & 3,844 & 0,677 & Within Gr. & 231,576 & 582 &, 398 & & & \\
\hline & $\mathrm{C}-\mathrm{Hs}$ & 212 & 3,641 & 0,661 & Total & 242,214 & 585 & & & & \\
\hline & $\begin{array}{l}\text { D- PEC + } \\
\text { SAC + VTC }\end{array}$ & 39 & 3,727 & 0,727 & & & & & & & \\
\hline & Total & 586 & 3,802 & 0,643 & & & & & & & \\
\hline \multirow{5}{*}{ 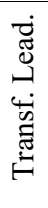 } & A-K/PS & 220 & 4,133 & 0,637 & Bet. Gr. & 20,681 & 3 & 6,894 & \multirow{5}{*}{12,672} & \multirow{5}{*}{, 000} & \multirow{5}{*}{$\begin{array}{l}A>C ; \\
B>C\end{array}$} \\
\hline & B-Ss & 115 & 3,993 & 0,776 & Within Gr. & 316,601 & 582 &, 544 & & & \\
\hline & C- Hs & 212 & 3,701 & 0,795 & Total & 337,282 & 585 & & & & \\
\hline & $\begin{array}{l}\text { D- PEC + } \\
\text { SAC + VTC }\end{array}$ & 39 & 3,917 & 0,823 & & & & & & & \\
\hline & Total & 586 & 3,935 & 0,759 & & & & & & & \\
\hline \multirow{5}{*}{ 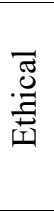 } & A-K/PS & 220 & 4,101 & 0,601 & Bet. Gr. & 12,164 & 3 & 4,055 & \multirow{5}{*}{8,371} & \multirow{5}{*}{, 000} & \multirow{5}{*}{$\begin{array}{l}\mathbf{A}>\mathbf{C} ; \\
\mathrm{B}>\mathrm{C}\end{array}$} \\
\hline & B-Ss & 115 & 4,098 & 0,690 & Within Gr. & 281,910 & 582 &, 484 & & & \\
\hline & $\mathrm{C}-\mathrm{Hs}$ & 212 & 3,795 & 0,781 & Total & 294,074 & 585 & & & & \\
\hline & $\begin{array}{l}\text { D- PEC + } \\
\text { SAC + VTC }\end{array}$ & 39 & 3,946 & 0,722 & & & & & & & \\
\hline & & 586 & 3,980 & 0,709 & & & & & & & \\
\hline \multirow{5}{*}{ 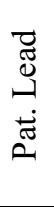 } & $\mathrm{A}-\mathrm{K} / \mathrm{PS}$ & 220 & 3,535 & 0,304 & Bet. Gr. & 2,832 & 3 & ,944 & \multirow{5}{*}{8,267} & \multirow{5}{*}{,000 } & \multirow{5}{*}{$\begin{array}{l}A>C ; \\
B>C\end{array}$} \\
\hline & B-Ss & 115 & 3,548 & 0,315 & Within Gr. & 66,459 & 582 &, 114 & & & \\
\hline & C- Hs & 212 & 3,396 & 0,376 & Total & 69,291 & 585 & & & & \\
\hline & $\begin{array}{l}\text { D- PEC + } \\
\text { SAC+ VTC }\end{array}$ & 39 & 3,540 & 0,367 & & & & & & & \\
\hline & Total & 586 & 3,488 & 0,344 & & & & & & & \\
\hline \multirow{5}{*}{ 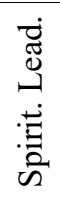 } & A-K/PS & 220 & 4,061 & 0,561 & Bet. Gr. & 11,329 & 3 & 3,776 & \multirow{5}{*}{8,896} & \multirow{5}{*}{,000 } & \multirow{5}{*}{$\begin{array}{l}\mathbf{A}>\mathbf{C} ; \\
\mathbf{B}>\mathbf{C}\end{array}$} \\
\hline & B-Ss & 115 & 3,987 & 0,645 & Within Gr. & 247,059 & 582 &, 424 & & & \\
\hline & C- Hs & 212 & 3,745 & 0,729 & Total & 258,387 & 585 & & & & \\
\hline & $\begin{array}{l}\text { D- PEC + } \\
\text { SAC + VTC }\end{array}$ & 39 & 3,924 & 0,699 & & & & & & & \\
\hline & Total & 586 & 3,923 & 0,665 & & & & & & & \\
\hline
\end{tabular}

K: Kindergarten, Ps: Primary school, Ss: Secondary school, Hs: High school, PEC: Public education centre, SAC: Science and art center, VTC: Vocational tarining center 
According to Table 5, teachers' perception of instructional, transformational, ethical, paternalist, and spiritual leadership styles of school administrators differ significantly according to the type of school variable $(\mathrm{p}<.05)$. Kindergarten / primary and secondary school level teachers' perception of instructive $(F=8,912 ; p<.05)$, transformational $(\mathrm{F}=12,672 ; \mathrm{p}<.05)$, ethical $(\mathrm{F}=8,371 ; \mathrm{p}<.05)$, paternalist $(\mathrm{F}=8,267) . ; \mathrm{p}<.05)$ and spiritual $(\mathrm{F}=8,896 ; \mathrm{p}<.05)$ leadership styles are higher than high school level teachers.

The results of One-Way ANOVA analysis conducted to determine whether the teachers' perceptions of instructional, transformational, ethical, paternalist, and spiritual leadership styles of school administrators differ significantly according to age variable.

According to Table 6, perceived instructional, transformational, ethical, paternalistic and spiritual leadership styles of school administrators differ significantly according to the ages of teachers $(\mathrm{p}<.05)$. Teachers aged 30 and below; perceptions of instructive $(F=5.047 ; \mathrm{p}<.05)$, transformational $(\mathrm{F}=3.998 ; \mathrm{p}<.05)$, ethical $(\mathrm{F}=5.892$; $\mathrm{p}<.05)$, paternalist $(\mathrm{F}=3.043 ; \mathrm{p}<.05)$ and spiritual $(\mathrm{F}=5.247 ; \mathrm{p}<.05)$ leadership styles are higher than teachers who are between 31 and 40 years old. In other words, teachers aged 30 and above perceive the instructional, transformational, ethical, paternalist, and spiritual leadership styles of school administrators more positively than teachers between ages 31-40.

Table 6. ANOVA Results of Teachers' Perceptions of Instructional, Transformational, Ethical, Paternalist, and Spiritual Leadership Styles of School Administrators According to Age Variable

\begin{tabular}{|c|c|c|c|c|c|c|c|c|c|c|c|}
\hline & Age & $\mathbf{N}$ & $\mathbf{M}$ & SD & $\begin{array}{l}\text { Source of } \\
\text { Variance }\end{array}$ & $\begin{array}{c}\text { Sum of } \\
\text { Squares }\end{array}$ & df & $\begin{array}{l}\text { Mean } \\
\text { quare }\end{array}$ & $\mathbf{F}$ & $\mathbf{p}$ & Sig. \\
\hline \multirow{5}{*}{ 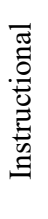 } & $\begin{array}{l}\text { A- } 30 \text { years } \\
\text { and below }\end{array}$ & 97 & 3,961 & ,659 & Bet. Gr. & 6,142 & 3 & 2,047 & \multirow{5}{*}{5,047} & \multirow{5}{*}{,002 } & \multirow{5}{*}{$\mathbf{A}>\mathbf{B}$} \\
\hline & B-31-40 & 241 & 3,691 & ,648 & Within Gr. & 236,072 & 582 &, 406 & & & \\
\hline & C-41-50 & 158 & 3,829 & ,637 & Total & 242,214 & 585 & & & & \\
\hline & D-51 years + & 90 & 3,884 &, 581 & & & & & & & \\
\hline & Total & 586 & 3,802 & ,643 & & & & & & & \\
\hline \multirow{5}{*}{ 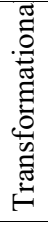 } & $\begin{array}{l}\text { A- } 30 \text { years } \\
\text { and below }\end{array}$ & 97 & 4,085 & ,792 & Bet. Gr. & 6,810 & 3 & 2,270 & \multirow{5}{*}{3,998} & \multirow{5}{*}{,008 } & \multirow{5}{*}{$\mathbf{A}>\mathbf{B}$} \\
\hline & B-31-40 & 241 & 3,813 & ,774 & Within Gr. & 330,472 & 582 & ,568 & & & \\
\hline & C-41-50 & 158 & 3,976 & ,731 & Total & 337,282 & 585 & & & & \\
\hline & D-51 years + & 90 & 4,029 & ,694 & & & & & & & \\
\hline & Total & 586 & 3,935 &, 759 & & & & & & & \\
\hline \multirow{5}{*}{ 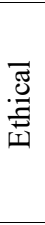 } & $\begin{array}{l}\text { A- } 30 \text { years } \\
\text { and below }\end{array}$ & 97 & 4,178 &, 722 & Bet. Gr. & 8,668 & 3 & 2,889 & \multirow{5}{*}{5,892} & \multirow{5}{*}{,001 } & \multirow{5}{*}{$\mathbf{A}>\mathbf{B}$} \\
\hline & B-31-40 & 241 & 3,849 &, 716 & Within Gr. & 285,406 & 582 &, 490 & & & \\
\hline & C-41-50 & 158 & 4,015 & ,681 & Total & 294,074 & 585 & & & & \\
\hline & D-51 years + & 90 & 4,054 & ,666 & & & & & & & \\
\hline & Total & 586 & 3,980 & ,709 & & & & & & & \\
\hline \multirow{5}{*}{ 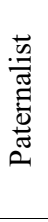 } & $\begin{array}{l}\text { A- } 30 \text { years } \\
\text { and below }\end{array}$ & 97 & 3,571 & ,406 & Bet. Gr. & 1,070 & 3 & ,357 & \multirow{5}{*}{3,043} & \multirow{5}{*}{, 028} & \multirow{5}{*}{$\mathbf{A}>\mathbf{B}$} \\
\hline & B-31-40 & 241 & 3,455 & ,321 & Within Gr. & 68,221 & 582 &, 117 & & & \\
\hline & C-41-50 & 158 & 3,468 &, 319 & Total & 69,291 & 585 & & & & \\
\hline & D-51 years + & 90 & 3,519 &, 362 & & & & & & & \\
\hline & Total & 586 & 3,488 & ,344 & & & & & & & \\
\hline \multirow{5}{*}{$\begin{array}{l}\text { 胥 } \\
\text { : } \\
\text { के }\end{array}$} & $\begin{array}{l}\text { A- } 30 \text { years } \\
\text { and below }\end{array}$ & 97 & 4,101 & ,685 & Bet. Gr. & 6,805 & 3 & 2,268 & \multirow{5}{*}{5,247} & \multirow{5}{*}{,001 } & \multirow{5}{*}{$\mathbf{A}>\mathbf{B}$} \\
\hline & B-31-40 & 241 & 3,812 & ,667 & Within Gr. & 251,583 & 582 &, 432 & & & \\
\hline & C-41-50 & 158 & 3,932 & ,639 & Total & 258,387 & 585 & & & & \\
\hline & D-51 years + & 90 & 4,014 & ,634 & & & & & & & \\
\hline & Total & 586 & 3,923 & ,665 & & & & & & & \\
\hline
\end{tabular}

The results of One-Way ANOVA analysis conducted to determine whether the instructional, transformational, ethical, paternalist, and spiritual leadership styles of school administrators differ significantly according to the seniority variable presented in Table 7 . 
Table 7. Comparison of the Instructional, Transformational, Ethical, Paternalist, and Spiritual Leadership Styles of School Administrators According to the Seniority Variable

\begin{tabular}{|c|c|c|c|c|c|c|c|c|c|c|c|}
\hline & Kıdem & $\mathbf{N}$ & $\mathbf{M}$ & SD & $\begin{array}{l}\text { Source of } \\
\text { Variance }\end{array}$ & $\begin{array}{c}\text { Sum of } \\
\text { Squares }\end{array}$ & df & $\begin{array}{l}\text { Mean } \\
\text { square }\end{array}$ & $\mathbf{F}$ & $\mathbf{p}$ & Sig. \\
\hline \multirow{6}{*}{ 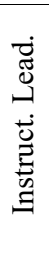 } & $\begin{array}{l}\text { A-5 years and } \\
\text { below }\end{array}$ & 81 & 3,887 &, 621 & Bet. Gr. & 3,094 & 4 & ,774 & \multirow{6}{*}{$-1,880$} & \multirow{6}{*}{,112 } & \multirow{6}{*}{---} \\
\hline & B-6-10 year & 153 & 3,714 & ,694 & Within Gr. & 239,119 & 581 &, 412 & & & \\
\hline & C- $11-15$ year & 102 & 3,760 & ,638 & Total & 242,214 & 585 & & & & \\
\hline & D- $16-20$ year & 73 & 3,768 &, 607 & & & & & & & \\
\hline & E- 21 year + & 177 & 3,879 & 618 & & & & & & & \\
\hline & Total & 586 & 3,802 & 643 & & & & & & & \\
\hline \multirow{6}{*}{ 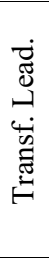 } & $\begin{array}{l}\text { A-5 years and } \\
\text { below }\end{array}$ & 81 & 4,064 &, 735 & Bet. Gr. & 5,242 & 4 & 1,310 & \multirow{6}{*}{$-2,293$} & \multirow{6}{*}{,058 } & \multirow{6}{*}{--- } \\
\hline & B-6-10 year & 153 & 3,837 &, 840 & Within Gr. & 332,040 & 581 & 5,571 & & & \\
\hline & C- $11-15$ year & 102 & 3,868 & ,737 & Total & 337,282 & 585 & & & & \\
\hline & D- $16-20$ year & 73 & 3,862 &, 750 & & & & & & & \\
\hline & E- 21 year + & 177 & 4,029 & ,699 & & & & & & & \\
\hline & Total & 586 & 3,935 &, 759 & & & & & & & \\
\hline \multirow{6}{*}{ 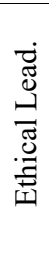 } & $\begin{array}{l}\text { A-5 years and } \\
\text { below }\end{array}$ & 81 & 4,107 & ,700 & Bet. Gr. & 5,043 & 4 & 1,261 & \multirow{6}{*}{$-2,534$} & \multirow{6}{*}{,039 } & \multirow{6}{*}{$\begin{array}{l}\mathbf{A}>\mathbf{B} ; \\
\mathbf{A}>\mathbf{C} \\
\mathbf{E}>\mathbf{B} ; \\
\mathbf{E}>\mathbf{C}\end{array}$} \\
\hline & B-6-10 year & 153 & 3,902 &, 767 & Within Gr. & 289,032 & 581 & ,497 & & & \\
\hline & C- $11-15$ year & 102 & 3,897 &, 718 & Total & 294,074 & 585 & & & & \\
\hline & D- $16-20$ year & 73 & 3,890 &, 657 & & & & & & & \\
\hline & E- 21 year + & 177 & 4,072 & ,662 & & & & & & & \\
\hline & Total & 586 & 3,980 & ,709 & & & & & & & \\
\hline \multirow{6}{*}{ 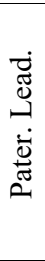 } & $\begin{array}{l}\text { A-5 years and } \\
\text { below }\end{array}$ & 81 & 3,571 & ,387 & Bet. Gr. & 1,123 & 4 & ,281 & \multirow{6}{*}{$-2,393$} & \multirow{6}{*}{, 050} & \multirow{6}{*}{---} \\
\hline & B-6-10 year & 153 & 3,445 & ,346 & Within Gr. & 68,168 & 581 &, 117 & & & \\
\hline & C- $11-15$ year & 102 & 3,502 & ,299 & Total & 69,291 & 585 & & & & \\
\hline & D- $16-20$ year & 73 & 3,432 &, 315 & & & & & & & \\
\hline & E- 21 y1l + & 177 & 3,501 &, 352 & & & & & & & \\
\hline & Total & 586 & 3,488 &, 344 & & & & & & & \\
\hline \multirow{6}{*}{ 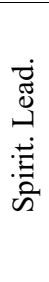 } & $\begin{array}{l}\text { A-5 years and } \\
\text { below }\end{array}$ & 81 & 4,033 & ,652 & Bet. Gr. & 3,835 & 4 & ,959 & \multirow{3}{*}{2,188} & \multirow{3}{*}{, 069} & \multirow{3}{*}{--} \\
\hline & B-6-10 year & 153 & 3,869 & ,714 & Within Gr. & 254,552 & 581 & ,438 & & & \\
\hline & C- $11-15$ year & 102 & 3,855 &, 642 & Total & 258,387 & 585 & & & & \\
\hline & D- $16-20$ year & 73 & 3,817 & ,635 & & & & & & & \\
\hline & E- 21 year + & 177 & 4,002 & ,641 & & & & & & & \\
\hline & Total & 586 & 3,923 &, 665 & & & & & & & \\
\hline
\end{tabular}

According to Table 7, instructional, transformational, paternalist, and spiritual leadership styles of school administrators do not differ significantly according to seniority variable $(p>.05)$.

However, the ethical leadership style of school administrators differs significantly according to the seniority of the teachers $(\mathrm{F}=2,534 ; \mathrm{p}<.05)$. Teachers with 5 years or less and 21 years or more seniority levels perceive the ethical leadership style of school administrators at a higher level than teachers with a seniority of 6-10 years and 11-15 years. In other words, teachers with a seniority of 5 years or less and 21 years or more think that school administrators exhibit more ethical leadership style than teachers with a seniority of 6-10 years and 1115 years.

The results of the One-Way ANOVA analysis conducted to determine whether the instructional, transformational, ethical, paternalist and spiritual leadership styles of the school principals differ significantly according to the duration of the teachers' working with the current school administrator or not are presented in Table 8 . 
Comparison of Ethical, Transformational, Paternalistic, Spiritual and Instructional Leadership Styles

Table 8. Comparison of Instructional, Transformational, Ethical, Paternalist and Spiritual Leadership Styles of School Administrators According to the Duration of Working with the Administrator

\begin{tabular}{|c|c|c|c|c|c|c|c|c|c|c|c|}
\hline & Duration & $\mathbf{N}$ & $\mathbf{M}$ & SD & $\begin{array}{l}\text { Source of } \\
\text { Variance }\end{array}$ & $\begin{array}{c}\text { Sum of } \\
\text { Squares }\end{array}$ & df & $\begin{array}{l}\text { Mean } \\
\text { square }\end{array}$ & $\mathbf{F}$ & $\mathbf{p}$ & Sig. \\
\hline \multirow{7}{*}{ 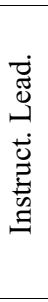 } & $\begin{array}{l}\text { A-1 year } \\
\text { and below }\end{array}$ & 264 & 3,787 & ,604 & Bet. Gr. & 2,448 & 5 & ,490 & \multirow{7}{*}{1,184} & \multirow{7}{*}{,315 } & \multirow{7}{*}{--- } \\
\hline & B- 2 years & 82 & 3,714 &, 702 & Within Gr. & 239,766 & 580 & ,413 & & & \\
\hline & C- 3 years & 82 & 3,846 & 629 & Total & 242,214 & 585 & & & & \\
\hline & D- 4 years & 57 & 3,734 &, 706 & & & & & & & \\
\hline & E- 5 years & 57 & 3,917 & ,709 & & & & & & & \\
\hline & F- 6 years + & 44 & 3,916 & 604 & & & & & & & \\
\hline & Total & 586 & 3,802 & ,643 & & & & & & & \\
\hline \multirow{7}{*}{ 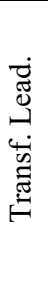 } & & 264 & 3,952 & ,688 & Bet. Gr. & 2,283 & 5 & ,457 & \multirow{7}{*}{,790 } & \multirow{7}{*}{, 557} & \multirow{7}{*}{--- } \\
\hline & B- 2 years & 82 & 3,813 &, 817 & Within Gr. & 334,999 & 580 & ,578 & & & \\
\hline & C- 3 years & 82 & 3,990 &, 772 & Total & 337,282 & 585 & & & & \\
\hline & D- 4 years & 57 & 3,851 &, 839 & & & & & & & \\
\hline & E- 5 years & 57 & 3,986 &, 805 & & & & & & & \\
\hline & $\begin{array}{l}\text { F- } 6 \\
\text { y1ears+ }\end{array}$ & 44 & 4,002 &, 867 & & & & & & & \\
\hline & Total & 586 & 3,935 & ,759 & & & & & & & \\
\hline \multirow{7}{*}{ 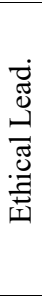 } & $\begin{array}{l}\text { A-1 year } \\
\text { and below }\end{array}$ & 264 & 3,978 & ,653 & Bet. Gr. & 1,550 & 5 &, 310 & \multirow{7}{*}{,615 } & \multirow{7}{*}{,689 } & \multirow{7}{*}{---} \\
\hline & B- 2 years & 82 & 3,916 &, 768 & Within Gr. & 292,524 & 580 & ,504 & & & \\
\hline & C- 3 years & 82 & 4,009 & ,699 & Total & 294,074 & 585 & & & & \\
\hline & D- 4 years & 57 & 3,891 &, 784 & & & & & & & \\
\hline & E- 5 years & 57 & 4,042 &, 756 & & & & & & & \\
\hline & F- 6 years + & 44 & 4,084 &, 790 & & & & & & & \\
\hline & Total & 586 & 3,980 &, 709 & & & & & & & \\
\hline \multirow{7}{*}{ 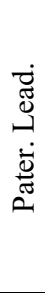 } & $\begin{array}{l}\text { A-1 year } \\
\text { and below }\end{array}$ & 264 & 3,509 & ,327 & Bet. Gr. & ,711 & 5 & ,142 & \multirow{7}{*}{1,203} & \multirow{7}{*}{,306 } & \multirow{7}{*}{--- } \\
\hline & B- 2 years & 82 & 3,407 & ,379 & Within Gr. & 68,580 & 580 & ,118 & & & \\
\hline & C- 3 years & 82 & 3,504 &, 367 & Total & 69,291 & 585 & & & & \\
\hline & D- 4 years & 57 & 3,502 & ,330 & & & & & & & \\
\hline & E- 5 years & 57 & 3,485 & ,359 & & & & & & & \\
\hline & F- 6 years + & 44 & 3,463 & ,324 & & & & & & & \\
\hline & Total & 586 & 3,488 &, 344 & & & & & & & \\
\hline \multirow{7}{*}{ 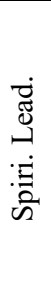 } & $\begin{array}{l}\text { A-1 year } \\
\text { and below }\end{array}$ & 264 & 3,939 & ,633 & Bet. Gr. & 1,920 & 5 & ,384 & \multirow{7}{*}{,868 } & \multirow{7}{*}{, 502} & \multirow{7}{*}{--- } \\
\hline & B- 2 y1l & 82 & 3,807 & ,750 & Within Gr. & 256,467 & 580 & ,442 & & & \\
\hline & C- 3 yil & 82 & 3,954 &, 643 & Total & 258,387 & 585 & & & & \\
\hline & D- 4 y1l & 57 & 3,865 & ,689 & & & & & & & \\
\hline & E- 5 yil & 57 & 4,013 & ,631 & & & & & & & \\
\hline & F- 6 years + & 44 & 3,943 &, 736 & & & & & & & \\
\hline & Total & 586 & 3,923 &, 665 & & & & & & & \\
\hline
\end{tabular}

According to Table 8, the instructional, transformational, paternalist, ethical, and spiritual leadership styles of school administrators do not differ significantly according to the duration of working with the administrator currently $(\mathrm{p}>$.05). In other words, teachers whose working duration are different from their current principals perceive their principals' instructional, transformational, paternalist, ethical, and spiritual leadership styles at a similar level.

\section{Conclusion and Discussion}

In this study, instructional, transformational, ethical, paternalist, and spiritual leadership styles of school administrators, teachers' demographic characteristics, and the relationship among these leadership styles have been examined. According to the first finding of the study, teachers think that school administrators' ethical, transformational, spiritual, instructional, and paternalist leadership styles are highly and positively correlated with each other. The fact that these leadership styles are positively correlated with each other proves that these leadership styles give us positive leadership behaviors and characteristics for teachers and the functioning of 
the organization. It has shown that teachers are able to perceive different leadership styles. For this reason, it is difficult to find the most effective leadership style. Therefore, applying these leadership styles, that have positive relationships with each other, can help teachers to reveal their potential in the most effective way. From highest to lowest, teachers' perception of the leadership styles of administrators, ethical leadership, transformational leadership, spiritual leadership, instructional leadership, and paternalist leadership respectively. This finding has given us the clue that principals most exhibit ethical leadership style and they least exhibit the paternalist leadership style behaviors. Teachers think that school administrators act in accordance with ethical principles within the school and take into account these principles in their decisions and practices.

Uğurlu (2009) and Kılınç (2010) revealed that school principals 'ethical leadership behavior can positively affect teachers' performance. On the other hand, teachers' perception of the paternalist leadership style of school principals who act as family members, authoritarian, and have good relationships is low when compared to other leadership styles. While Özgenel and Dursun (2020) determined school administrators' paternalist leadership behaviors at a "moderate" level, according to perceptions of teachers, Dağlı and Ağalday (2018) and Aktaş (2019) concluded that the perception of paternalist leader behaviors among school principals was higher.Some studies (Çetinkaya, 2011; Gündüz \& Doğan, 2009; Kazanc1, 2010; Özcan 2013) revealed that school principals display the transformational leadership style at the highest level according to teachers' perceptions. Smith (2008), Günay Süle (2019), and Ankaralığlu (2020) found in their studies that spiritual leaders make decisions by considering their strong moral convictions and what is best for the organization. According to Daşkın (2019) and Ail et al. (2015) school administrators need to use instructional leadership skills to improve teachers' commitment to the organization and according to another finding obtained from the research was that school administrators "mostly" performed instructional leadership behaviors due to the teachers' opinions. Within the framework of the results obtained by the studies have shown that teachers can be affected by different leadership styles at different levels. In this case, it would be appropriate for school principals to use different leadership styles in line with the dynamics of the group to ensure teachers' potential at the highest level. According to another important result of the study, there is no significant difference among undergraduate and graduate teachers 'perceptions of school principals' ethical, transformational, spiritual, instructional, and paternalist leadership styles. This result is consistent with Kaya's (2020) study, it is found that the graduation degree variable of teachers did not cause a difference in the opinions of the school principal regarding ethical leadership performance. Akıncı (2017) and Günay Süle (2019) stated that there is no significant difference between the perceptions of spiritual leadership of undergraduate teachers and graduate graduates. According to the data obtained from Zengin's (2019) study, it was revealed that teachers 'perceptions of school administrators' transformational leadership characteristics did not differ significantly due to the educational status variable. Önsal (2012) stated in his paternalist leadership study that teachers' perceptions did not change. Therefore, in the context of the results of this study, it can be said that there is no significant difference in teachers 'assessment of school administrators' leadership styles as the education status variable increases.

In this study, it was concluded that the perceptions of leadership styles decreased as the school level in which teachers worked respectively from kindergarten / primary school, secondary school to high school. In other words, as the school level progresses, teachers think that school principals' ethical leadership, transformational leadership, spiritual leadership, instructional leadership, and paternalist leadership behaviors decrease. While Tosun (2015) and Zengin (2019) did not determine a significant difference in transformational leadership behaviors, also Bağdatli (2015) did not state any difference in paternalist leadership behaviors. It is seen that Akınc1 (2017) encountered a significant difference in mental leadership behaviors and Yilmaz (2010) in instructional leadership behaviors.

This situation can be interpreted as, it can be said that as the types of school and leadership styles differ, the results are changeable, and a clear interpretation cannot be obtained in this direction. Perceptions of teachers on school administrators' instructional, transformational, ethical, paternalist, and spiritual leadership styles differ significantly according to age variable. Teachers under 30 years of age have more positive perceptions 
of instructional, transformational, ethical, paternalistic, and spiritual leadership styles than teachers between 31-40 years of age. Antonakis, Avalio, and Sivasubramaniam (2003) and Eagly, Johannesen-Schmidt, and Van Engen (2003) concluded a result that the level of perception transformational, sustaining, and liberating leadership style increases due to age variable among the samples. Akgüney (2013), in his research examining the effects of mental leadership on organizational outcomes, concluded that the older the age, the higher the perception of spiritual leadership. Kaya (2020) concluded that perceptions of administrators' ethical leadership behaviors are higher at 51 years and above than teachers in other age groups. Contrary to these studies, Dursun (2019) and Aydınoğlu (2020) concluded that the age variable is not effective in paternalist leadership behaviors. The results of this study can be explained by the fact that as the age variable increases, teachers' observation, and evaluation level of the leadership styles becomes better. When teachers' perceptions of leadership styles are compared according to their seniority variable; teachers with 5 years or less seniority have higher perceptions of ethical leadership than teachers with 6-10 years and 11-15 years of seniority. Perceptions of ethical leadership of teachers with seniority of 21 years or more are higher than teachers with seniority between 6-10 and 11-15 years. Emirbey (2017) found in a similar study that ethical leadership behaviors show an increasing trend according to the professional seniority of teachers.

Teachers' perceptions of transformational leadership, paternalist leadership, instructional leadership and spiritual leadership do not differ according to their seniority variable. Memişoğlu (2006), Suliman and Iles (2000) and Vugt, Jepson, Hart, and Cremer (2004) concluded that leadership styles do not make a significant difference according to the seniority variable. In their studies measuring Manafzadehtabriz (2020) transformational leadership, Sever (2020) instructional leadership, and Arslan (2016) paternalist leadership behaviors, they concluded that the professional seniority variable did not make a significant difference. While the seniority variable is expected to create a significant difference as it affects the age variable, on the contrary, the differences we see in most of the leadership behaviors are thought to be that teachers evaluate the leadership styles of school administrators better as a result of experience. Finally, there is no significant difference between teachers' perceptions of transformational, instructional, ethical, spiritual, and paternalist leadership styles according to the duration variable with the current principals. Similarly, Tahaoğlu and Gedikoğlu (2009) stated that teachers 'perceptions of school principals' fulfillment of transformational leadership roles do not change according to the term of office. According to Sever (2020) teachers; transformational, instructional, and ethical leadership and Aktaş (2019) paternalist leadership behaviors did not cause a significant difference in working time with the principal. In the context of the results of this study, the tenure of the teachers in their school did not make a difference in the perception level of the school administrators' leadership style.It can be explained by the fact that the leadership style exhibited by the school principal has not changed over the years. If the effects of these leadership styles on teachers and school outcomes are examined in future studies, stronger generalizations will be made.

\section{References}

Abdullah, A., Alzaidiyeen, N. J., \& Aldarabah, I. T. (2009). Workplace spirituality and leadership effectiveness among educational managers in Malaysia. European Journal of Social Sciences, 10(2), 304-316.

Ail, N. M. B. M., bin Taib, M. R., bt Jaafar, H., \& bin Omar, M. N. (2015). Principals' instructional leadership and teachers' commitment in three Mara Junior Science Colleges (Mjsc) in Pahang, Malaysia. ProcediaSocial and Behavioral Sciences, 191, 1848-1853.

Akan, D. Yıldırım, İ. ve Yalçın, S. (2014). Okul müdürleri liderlik stilleri ölçeğinin geliştirilmesi. Electronic Journal of Social Sciences, 13(51), 392-415.

Akgüney, E. (2013). Ruhsal liderliğin örgütsel çıktlara etkisi: Bankacllık ve faizsiz finans sektörleri arasında karşılaştırmalı bir analiz (Yayınlanmamış Yüksek Lisans Tezi). Gebze Yüksek Teknoloji Enstitüsü, Gebze.

Akıncı, T. (2017). Lise ögretmenlerinin yönetici ruhsal liderlik algllarının öğretmen liderliği ve özyetkinliklerine etkisi (Yayımlanmamış doktora tezi). Marmara Üniversitesi ve İstanbul Sabahattin Zaim Üniversitesi, Eğitim Yönetimi ve Denetimi Ortak Lisansüstü Programı, İstanbul.

Akıncı, T., \& Ekşi, H. (2017). Yönetici ruhsal liderlik algı ölçeği geliştirilmesi. Route Educational and Social Science Journal, 4(7), 294-312. 
Aktaş, T. (2019). Okul müdürlerinin paternalist liderlik davranışları ile politik taktikleri arasındaki ilişki (Yayınlanmamış yüksek lisans tezi). Pamukkale Üniversitesi, Denizli.

Albrecht, S. L., Bakker, A. B., Gruman, J. A., Macey, W. H., \& Saks, A. M. (2015). Employee engage- ment, human resource management practices and competitive advantage. Journal of Organizational Effectivenes, 2(1), 7-35. doi:10.1108/JOEPP-08-2014-0042

Altınkurt, Y. (2007). Eğitim örgütlerinde stratejik liderlik ve okul müdürlerinin stratejik liderlik uygulamaları (Yayınlanmamış doktora tezi). Anadolu Üniversitesi, Eskişehir.

Ankaralığlu, S. (2020). Farkl okul kademelerinde görev yapan ögrretmen algllarına göre yöneticilerin ruhsal liderlik stilinin okul kültürüne etkisi (Yayınlanmamış yüksek lisans tezi). İstanbul Sabahattin Zaim Üniversitesi, İstanbul.

Antonakis, J., Avolio, B. J., \& Sivasubramaniam, N. (2003). Contextand leadership: An examination of the nine-factorfull-range leadership theory using the multifactor leadership questionnaire. Leadership Quarterly, 14, 261- 295.

Arslan, Ö. (2016). Okul yöneticilerinin paternalist liderlik düzeyleri ile ögretmenlerin örgütsel sinizm alglları arasındaki ilişki (Yayınlanmamış yüksek lisans tezi). Uşak Üniversitesi, Uşak.

Avey, J. B., Wernsing, T. S., \& Palanski, M. E. (2012). Exploring the process of ethical leadership: The mediating role of employee voice and psychological ownership. Journal of Business Ethics, 107, 21-34. doi:10.1007/s10551-012-1298-2

Avolio, B. J., Bass, B. M., \& Jung, D. I. (1999). Re-examining the components of transformational and transactional leadership using the Multifactor Leadership Questionnaire. Journal of Occupational and Organizational Psychology, 72, 441-462.

Avolio, B. J., \& Bass, B. M. (1991). The full range leadership development programs: Basic and advanced manuals. New York, NY: Bass \& Avolio Associates.

Aycan, Z. (2006). Paternalism: Towards conceptual refinement and operationalization. In U. Kim, K. Yang ve K. Hwang (Eds.), Indigenous and cultural psychologies: Understanding People in context (pp. 445-466). New York: Springer Science.

Aycan, Z., Schyns, B., Sun, J. M., Felfe, J., \& Saher, N. (2013). Convergence and divergence of paternalistic leadership: A cross-cultural investigation of prototypes. Journal of International Business Studies, 44, 962969.

Aydınoğlu, N. (2020). Yöneticilerin otantik ve paternalist liderlik davranışlarının öğretmenlerin motivasyon, iş tatmini ve örgüt bağlılığına etkilerinin incelenmesi (Ankara özel okullar örneği) (Yayımlanmamış doktora tezi). İstanbul Gelişim Üniversitesi, İstanbul.

Bağdatlı, F. (2015). Okul yöneticilerinin çatışma yönetimi stilleri ile örgüt kültürü arasındaki ilişki. (Yayımlanmamış yüksek lisans tezi). İstanbul Sabahattin Zaim Üniversitesi, İstanbul.

Balcı, A. (2002). Türkiye'de eğitim yöneticilerinin yetiştirilmesi nasıl olmalı? 21. Yüzyıl Eğitim Yöneticilerinin Yetistirilmesi Sempozyumu, 16-17 Mayıs 2002, Ankara.

Baloğlu, N., \& Karadağ, E. (2009). Ruhsal liderlik üzerine teorik bir çözümleme. Kuram ve Uygulamada Eğitim Yönetimi, 15(58), 165-190.

Bass, B. M. (1999), Two decades of research and development in transformational leadership. European Journal of Work and Organizational Psychology, 8(1), 9-32.

Bass, B. M., \& Bass, R. (2008). The bass handbook of leadership: Theory, research, and managerial applications. New York: The Free Press.

Bozkuş, K. ve Gündüz, Y. (2016). Ruhsal liderlik ile örgütsel bağlllık arasındaki ilişkinin modellenmesi. Kastamonu Education Journal, 24(1), 405-420.

Breevaart, K., Bakker, A. B., Hetland, J., Demerouti, E., Olsen, O. K., \& Espevik, R. (2014). Daily transactional and transformational leadership and daily employee engagement. Journal of Occupational and Organizational Psychology, 87, 138-157. doi:10.1111/joop.12041

Brown, M. E., Treviño, L. K., \& Harrison, D. A. (2005). Ethical leadership: A social learning perspective for construct development and testing. Organizational Behavior and Human Decision Processes, 97, 117-134. doi:10.1016/j.obhdp.2005.03.002

Bryk, A. S., Sebring, P. B., Allensworth, E., Luppescu, S., \& Easton, J. (2010). Organizing schools for improvement: Lessons from Chicago. Chicago, IL: University of Chicago Press.

Bryman, A. (1992). Charisma and leadership in organizations. Sage Pub.

Bush, T. (2009) Leadership development and school improvement: contemporary issues in leadership development. Educational Review, 61(4), 375-389.

Büyüköztürk, Ş. (2012). Örnekleme yöntemleri. http://w3.balikesir.edu.tr/ msackes/wp/wpcontent/uploads/2012/03/BAY-Final-Konulari.pdf 
Can, N. (2002). Değisşim sürecinde eğitim yönetimi. Milli Eğitim Dergisi, 5, 17.

Chan, S. C. H., \& Mak, W. M. (2012). Benevolent leadership and follower performance: The mediating role of leader-member exchange (LMX). Asia Pacific Journal of Management, 29, 285-301.

Chan, S. C., Huang, X., Snape, E., \& Lam, C. K. (2013). The Janus face of paternalistic leaders: Authoritarianism, benevolence, subordinates' organization-based self-esteem, and performance. Journal of Organizational Behavior, 34(1), 108-128.

Chen, C. Y., \& Yang, C. F. (2012). The impact of spiritual leadership on organizational citizenship behavior: A multi-sample analysis. Journal of Business Ethics, 105(1), 107-114. https:// doi.org/10.1007/s10551011-0953-3

Chen, C. Y., Chen, C. H. V., \& Li, C. I. (2013). The influence of leader's spiritual values of servant leadership on employee motivational autonomy and eudaemonic well-being. Journal of Religion and Health, 52(2), 418-438. https://doi.org/10.1007/ s10943-011-9479-3

Chen, X. P., Eberly, M. B., Chiang, T. J., Farh, J. L., \& Cheng, B. S. (2014). Affective trust in Chinese leaders: Linking paternalistic leadership to employee performance. Journal of Management, 40, 796-819.

Cheng, B. S., Chou, L. F., Wu, T. Y., Huang, M. P. \& Farh, J. L. (2004). Paternalist leadership and subordinate responses: Establishing a leader model in chinese organizations. Asian Journal of Social Psychology, 7: 89-117.

Cohen, J., McCabe, E., M. Michelli N. M. and Pickeral, T. (2009) School climate: research, policy, practice, and teacher education. Teachers College Record, 111(1), 180-213.

Çetinkaya, İ. (2011). Ortaöğretim okul müdürlerinin liderlik stilleri ve iletişim becerileri arasındaki ilişski (Yüksek Lisans Tezi). Gazi Üniversitesi, Ankara.

Dağlı, A. ve Ardıç, T. (2014). Ortaokullarda görevli öğretmenlerin ruhsal liderliğe ilişkin algıları. Electronic Journal of Education Sciences, 3(5), 56-73.

Dağlı, A., \& A ğalday, B. (2018). Okul müdürlerinin paternalist liderlik davranışlarının incelenmesi. Electronic Journal of Social Sciences, 17(66).

Daşkın, S. (2019). Illkokul müdürlerinin öğretimsel liderlik rolleri (Yayınlanmamış yüksek lisans tezi). Dokuz Eylül Üniversitesi, İzmir.

Deal, T. (2005). Poetical and political leadership. In B. Davies, (Ed.), The Essentials of school leadership. London: Paul Chapman.

Den Hartog, D., \& De Hoogh, A. (2008). Empowering behaviour and leader fairness and integrity: Studying perceptions of ethical leader behaviour from a levels-of-analysis perspective. European Journal of Work and Organizational Psychology, 18, 199-230. doi:10.1080/13594320802362688

DePree, M. (1992). Leadership jazz. New York, NY: Bantam Doubleday Dell Publishing Group. Inc. Ehrhart.

Dursun, İ. E. (2019). Okul müdürlerinin paternalist liderlik davranışlarının okul kültürü oluşturmadaki etkisi (Yayınlanamış yüksek lisans tezi). İstanbul Sabahattin Zaim Üniversitesi, İstanbul.

Duyar, I., Gumus, S., \& Bellibas, M. S. (2013). Multilevel analysis of teacher work attitudes: The influence of principal leadership and teacher collaboration. International Journal of Educational Management 27(7), 700-719.

Eagly, A. H., Johannesen-Schmidt, M. C., \& Van Engen, M. L. (2003). Transformational, transactional and laissez-faire leadership styles: A meta-analysis comparing women and men. Psychological Bulletin, 129(4), 569-585.

Egel, E., \& Fry, L. W. (2017). Spiritual leadership as a model for Islamic leadership. Public Integrity, 19(1), 77-95. https://doi.org/10.1080/10999922.2016.1200411

Eren, A. (2020). İlkokul müdürlerinin öğretimsel liderlik davranışları ile etkili okul arasındaki ilişsi (Yayınlanmamış yüksek lisans tezi). Gazi Üniversitesi, Ankara.

Erkutlu, H. (2008). The impact of transformational leadership on organizational and leadership effectiveness: The Turkish case. Journal of Management Development, 27(7), 708-726. doi:10.1108/02621710810883616.

Eyal, O., Berkovich, I., \& Schwartz, T. (2011). Making the right choices: ethical judgments among educational leaders. Journal of Educational Administration, 49(4) 396-413.

Fairholm, G. (1996). Spiritual leadership: Fulfilling whole-self needs at work. Leadership \& Organization Development Journal, 17(5), 11-36.

Farh, J. L., \& Cheng, B. S. (2000). A Cultural analysis of paternalistic leadership in Chinese organizations. In J. T. Li, A. S. Tsui, and E. Weldon (Eds.), Management and organizations in the Chinese context (pp. 94127). London, England: Macmillan.

Fraenkel, J. R., Wallen, N. E., \& Hyun, H. H. (2012). How to design and evaluate research in education (Vol. 8). New York: McGraw-Hill. 
Fry, L. W. (2003). Toward a theory of spiritual leadership. The Leadership Quarterly. 14, 693-727.

Fry, L. W., \& Slocum, J. W. (2008). Maximizing the triple bottom line through spiritual leadership. Organizational Dynamics, 37(1), 86-96.

Fry, L. W., Vitucci, S., \& Cedillo, M. (2005). Spiritual leadership and army transformation: Theory, measurement, and estab- lishing a baseline. The Leadership Quarterly, 16(5), 835-862. https://doi.org/10.1016/j.leaqua.2005.07.012

Ghadi, M. Y., Fernando, M., \& Caputi, P. (2013). Transformational leadership and work engagement: The mediating effect of meaning in work. Leadership \& Organization Development Journal, 34(6), 535-550.

Glickman, C. (1989) Has Sam and Samantha's time come at last? Educational Leadership 46(8), 4-9.

Greenlee, B. and Brown, J. J. (2009). Retaining teachers in challenging schools. Education 130(1), 96-109.

Gumus, S., \& Akcaoglu, M. (2013). instructional leadership in Turkish primary schools: An analysis of teachers' perceptions and current policy. Educational Management Administration \& Leadership, 41(3), 289-302.

Gumus, S., Bellibas, M. S., Esen, M., \& Gumus, E. (2018). A systematic review of studies on leadership models in educational research from 1980 to 2014. Educational Management Administration \& Leadership, 46(1), 25-48. https://doi.org/10.1177/1741143216659296

Günay Süle, G. (2019). Okul yöneticilerinin kişilik özellikleri ile ruhsal liderlik düzeyleri arasındaki ilişki (Yayınlanmamış yüksek lisans tezi). Adnan Menderes Üniversitesi, Aydın

Gündüz, H. B. ve Doğan, A. (2009). Okul yöneticilerinin liderlik stilleri ve yaratıcılık düzeyleri. First International Congress of Educational Research.

Hallinger, P. and Murphy, J. (1985) Assessing the instructional leadership behavior of principals. Elementary School Journal, 86(2), 217-248.

Hallinger, P., \& Heck, R. H. (1998). Exploring the principal's contribution to school effectiveness: 1980-1995. School Effectiveness and School Improvement, 9, 157-191.

Hawkes, A. J., Biggs, A., \& Hegerty, E. (2017). Work engagement: Investigating the role of transformational leadership, job resources, and recovery. The Journal of Psychology, 151(6), 509-531.

Hayati, D., Charkhabi, M., \& Naami, A. Z. (2014). The relationship between transformational leader- ship and work engagement in governmental hospitals nurses: A survey study. Springer Plus, 3(1), 1-7. doi:10.1186/2193-1801-3-25

House, R. J., Hanges, P. J., Javidan, M., Dorfman, P. W., \& Gupta, V. (Eds.). (2004). Culture, leadership, and organizations: The GLOBE study of 62 societies. Sage publications.

Jung, D. I., Chow, C., \& Wu, A. (2003). The role of transformational leadership in enhancing organiza- tional innovation: Hypotheses and some preliminary findings. The Leadership Quarterly, 14, 525- 544. doi:10.1016/S1048-9843(03)00050-X

Kalkan, U., Altınay Aksal, F., Altınay Gazi, Z., Atasoy, R., \& Dağlı, G. (2020). The relationship between school administrators' leadership styles, school culture, and organizational image. SAGE Open. https://doi.org/10.1177/2158244020902081

Karadağ, M., Altınay Aksal, F., Altınay Gazi, Z., \& Dağli, G. (2020). Effect size of spiritual leadership: In the process of school culture and academic success. SAGE Open. https://doi.org/10.1177/2158244020914638

Karakitapoğlu-Aygün, Z., Gumusluoglu, L., \& Scandura, T. A. (2019). How do different faces of paternalistic leaders facilitate or impair task and innovative performance? Opening the Black Box. Journal of Leadership \& Organizational Studies, 27(2), 138-152. https://doi.org/10.1177/1548051819833380

Kaya, O. (2020). Okul yöneticilerinin etik liderlik davranışları ile öğretmenlerin sosyal sermaye düzeyleri arasındaki ilişkinin incelenmesi (Yayınlanmamış doktora tezi). Gaziantep Üniversitesi, Gaziantep.

Kazancı, N. (2010). İlköğretim okullarındaki yöneticilerin liderlik stilleri ile öğretmenlerin örgütsel adalet algıları arasındaki ilişki düzeyi (Yayımlanmamış yüksek lisans tezi). Sakarya Üniversitesi, Sakarya.

Kılınç, K. (2009). Dershane ve ilkögretim ögretmenlerinin algllarına göre yöneticilerinin liderlik stilleri (İstanbul İli Anadolu Yakası Örneği). Yeditepe Üniversitesi, İstanbul.

Kim, W. G., \& Brymer, R. A. (2011). The effects of ethical leadership on manager job satisfaction, commitment, behavioral outcomes, and firm performance. International Journal of Hospitality Management, 30, 1020-1026. doi:10.1016/j.ijhm.2011.03.008

King, D. (2002). The changing shape of leadership. Educational Leadership 59(8), 61-63.

Koç, A., \& Bastas, M. (2019b). Project schools as a school-based management model. International Online Journal of Education and Teaching, 6(4), 923-942.

Koçyiğit, M. (2017). The effect of school culture on student achievement. In E. Karadağ (Ed.), The factors affecting student achievement: Meta-analysis of empirical studies (pp. 183-197). Springer. 
Comparison of Ethical, Transformational, Paternalistic, Spiritual and Instructional Leadership Styles

Krishnakumar, S., Houghton, J. D., Neck, C. P., \& Ellison, C. N. (2015). The "good" and the "bad" of spiritual leadership. Journal of Management. Spirituality \& Religion, 12(1), 17-37. https://doi.org/10.1080/14766086.2014.886518

Krug, S. E. (1992). Instructional leadership: A constructivist perspective. Educational Administration Quarterly, 28(3), 430-443.

Kwan, P. (2020). Is transformational leadership theory passé? Revisiting the integrative effect of instructional leadership and transformational leadership on student outcomes. Educational Administration Quarterly, 56(2), 321-349.

Law, P. (2008). Developing spiritual leaders for the modern organi- zation. Management Today, 24(5), 20-22.

Leithwood, K., Louis, K. S., Anderson, S., \& Wahlstrom, K. (2004). How leadership influences student learning: Executive summary. Minneapolis: University of Minnesota Center for Applied Research and Educational Improvement.

Malone, P. F., \& Fry, L. W. (2003). Transforming schools through spiritual leadership: A field experiment. In Annual Meeting of the Academy of Management, (1-6 Ağustos). Seattle-Washington.

Malone, P., \& Fry, L. W. (2003, January 5). Transforming schools through spiritual leadership: A field experiment [Paper presentation]. National Meeting of the Academy of Management, Seattle, WA, United States.

Manafzadehtabriz, S. (2020). Üniversite yöneticilerinin ruhsal zekâ ve duygusal zekâ ile dönüşümcü liderlik davranışları arasındaki ilişkinin incelenmesi. (Yayınlanmamış doktora tezi). Uludağ Üniversitesi, Bursa.

Marks MH and Printy MS (2003) Principal leadership and school performance: an integration of transformational and instructional leadership. Educational Administration Quarterly 39(3), 370-397.

Memişoğlu, S. P. (2006). Lise müdürlerinin liderlik özelliklerine ilişkin öğretmen görüşleri. Abant İzzet Baysal Üniversitesi Ë̆itim Fakültesi Dergisi, 6(1) 179-189.

Mert, P., \& Ozgenel, M. (2020). A relational research on paternalist leadership behaviors perceived by teachers and teachers' performance. Educational Policy Analysis and Strategic Research, 15(2), 41-60.

Mitroff, I. I., \& Denton, E. A. (1999). A study of spirituality in the workplace. MIT Sloan Management Review, 40(4), 83-92.

Muharrem, T., Bircan, H., \& Yeşiltaş, M. (2012). Etik liderlik ölçeğinin geçerlilik ve güvenilirlik çalişması: Antalya örneği. Atatürk Üniversitesi Iktisadi ve İdari Bilimler Dergisi, 26(2), 143-155.

Önsal, A. (2012). Okul müdürlerinin iletişim becerileri ile okul kültürü arasındaki ilişsi (Yüksek lisans tezi). Maltepe Üniversitesi, İstanbul.

Özcan, A. (2013). İlköğretim okulu ögretmenlerinin algılarina göre okul müdürlerinin ve eğitim denetmenlerinin liderlik stilleri (Yayımlanmamış yüksek lisans tezi). Dokuz Eylül Üniversitesi, İzmir.

Özdemir, S. (2000). Eğitimde örgütsel yenileşme. Pegem.

Özgan, H., Bulut, L., Bulut, A., \& Bozbayındır, F. (2013). Okul müdürlerinin ruhsal liderliklerinin öğretmenlerin motivasyon düzeyi üzerindeki etkisi. Uşak Üniversitesi Sosyal Bilimler Dergisi, 6(1), 7083.

Özgenel, M. \& Aksu, T. (2020). The power of school principals' ethical leadership behavior to predict organizational health. International Journal of Evaluation and Research in Education (IJERE), 9(4), 101111. http://doi.org/10.11591/ijere.v9i4.20658

Özgenel, M. \& Ankaralığlu, S. (2020). The effect of school administrators'spiritual leadership style on school culture. Spiritual Psychology and Counseling, 5, 137-165. https://dx.doi.org/10.37898/spc.2020.5.2.93

Özgenel, M. \& Canuylası, R. (2021). Okul müdürlerinin paternalist liderlik davranışlarının örgütsel mutluluğa etkisi [The effect of paternalist leadership behaviors of school principals on organizational happiness]. Eğitim ve Teknoloji, 3(1), 14-31.

Özgenel, M. \& Dil, İ. (2020). Okul yöneticilerinin öğretimsel liderlik davranışlarının öğretmen motivasyonuna etkisi. FSM Eğitim Araştırmaları Kongresi, 09-10 Mayıs 2020, İstanbul/Türkiye.

Özgenel, M. \& Hıdıroğlu, A. (2019). Liderlik stillerine göre ortaya çıkan bir tutum: Örgütsel sinizm [An attitude that arises according to leadership styles: Organizational cynicism]. Journal of Kırşsehir Education Faculty, 20(2), 1003-1043.

Özgenel, M. \& Karsantik, İ. (2020). Effects of school principals' leadership styles on leadership practices. MOJES: Malaysian Online Journal of Educational Sciences, 8(2), 1-13.

Özgenel, M. \& Yayık, D. (2019). Okul müdürlerinin etik liderlik özellikleri ile okul iklimi ve öğretmenlerin okula bağl1lıkları arasındaki ilişkiler örüntüsü. $6^{\text {th }}$ International Symposium on Academic Studies in Educational and Social Sciences, June 13-15, 2019, Ankara, Turkey.

Özgenel, M. \& Dursun, İ. E. (2020). Okul müdürlerinin paternalist liderlik davranışlarının okul kültürüne etkisi. Sosyal, Beşerî ve İdari Bilimler Dergisi, 3(4), 284-302. 
Özgenel, M., Baydar, F. \& Baydar, H. (2019). Okul yöneticilerinin etik liderlik yeterlikleri ile örgütsel muhalefet arasındaki ilişki. $3^{\text {rd }}$ Internatıonal Congress of Eurasian Socıal Sciences, 18-21 April 2019, Bodrum/Muğla.

Öztürk, E. K. (2018). Stratejik düşünme ve politik yeteneklerin dönüşümcü liderlik üzerine etkileri (Yayımlanmamış doktora tezi). Gebze Teknik Üniversitesi, Kocaeli.

Parker, S. K., \& Griffin, M. A. (2011). Understanding active psychological states: Embedding engagement in a wider nomological net and closer attention to performance. European Journal of Work and Organizational Psychology, 20(1), 60-67. doi:10.1080/1359432X.2010.532869

Pellegrini, E. K., \& Scandura, T. A. (2008). Paternalistic lead- ership: A review and agenda for future research. Journal of Management, 4, 566-593.

Philipp, B. L. U., \& Lopez, P. D. J. (2013). The moderating role of ethical leadership: Investigating relationships among employee psychological contracts, commitment, and citizenship behavior. Journal of Leadership \& Organizational Studies, 20(3), 304-315. https://doi.org/10.1177/1548051813483837

Pio, R. J., \& Tampi, J. R. E. (2018). The influence of spiritual lead- ership on quality of work life, job satisfaction and organiza- tional citizenship behavior. International Journal of Law and Management, 60(2), 757-767. https://doi.org/10.1108/IJLMA- 03-2017-0028

Podsakoff, P., MacKenzie, S., \& Bommer, W. (1996). Transformational leader behaviors and substitutes for leader- ship as determinants of employee satisfaction, commitment, trust, and organizational citizenship behaviors. Journal of Management, 22, 259-299.

Rego, A., Sousa, F., Marques, C., \& Cunha, M. P. (2012). Authentic leadership promoting employee's psychological capital and creativity. Journal of Business Research, 65, 429-437.

Robinson, V., Lloyd, C., and Rowe, K. (2008). The impact of leadership on student outcomes: an analysis of the differential effects of leadership types. Educational Administration Quarterly 44(5), 564-588.

Ross, J. A. and Gray, P. (2006). School leadership and student achievement: the mediating effects of teacher beliefs. Canadian Journal of Education 29(3), 798-822.

Salehzadeh, R., Khazaei Pool, J., Kia Lashaki, J., Dolati, H., \& Balouei Jamkhaneh, H. (2015). Studying the effect of spiritual leadership on organizational performance: An empirical study in hotel industry. International Journal of Culture, Tourism and Hospitality Research, 9(3), 346-359. https://doi.org/10.1108/ IJCTHR-03-2015-0012

Sanders, J. E., Hopkins, W. E., \& Geroy, G. D. (2003). From trans- actional to transcendental: Toward an integrated theory of leadership. Journal of Leadership \& Organizational Studies, 9(4), 21-31. https://doi.org/10.1177/107179190300900402

Sever, N. (2020). Okul müdürlerinin liderlik stilleri ile okulların örgütsel çekicilikleri arasındaki ilişkinin incelenmesi (Yayınlanmamış yüksek lisans tezi). İnönü Üniversitesi, Malatya.

Sheppard, B. (1996). Exploring the transformational nature of instructional leadership. Alberta Journal of Educational Research 42(4), 325-344.

Smith, S. L. (2007). Spiritual leadership as an effective leadership style fort he public school superintendent (Doctoral dissertation). Duquesne University, USA

Song, C. (2016). Supervisors' paternalistic leadership influences college English teachers' teaching efficacy in China. Social Behavior and Personality, 44, 1315-1328.

Starratt, R. (2005). Ethical leadership. In Davies, B. (Ed.), The essentials of school leadership. London: Paul Chapman.

Stefkovich, J., \& Begley, P. (2007) Ethical school leadership: Defining the best interests of students. Educational Management Administration \& Leadership, 35(2), 205-24.

Suliman, A. \& Iles, P. (2000). Is contınuous commitment beneficial to organizations? commitmentperformancere lationship: A newlook. Journal of Manageria Lpsychology. 15(5), 407-426.

Supovitz, J., Sirinides, P., \& May, H. (2010). How principals and peers influence teaching and learning. Educational Administration Quarterly, 46, 31-56.

Şahin, S. (2005). İlköğretim okulu müdürlerinin dönüşümcü ve sürdürümcü liderlik stilleri (İzmir İli Örneği). Eğitim ve Bilim, 30(135), 39-49.

Şahin, S. (2011). Öğretimsel liderlik ve okul kültürü arasındaki ilişki (İzmir ili örneği). Kuram ve Uygulamada Eğitim Bilimleri, 11(4), 1909-1928.

Tahaoğlu, F. ve Gedikoğlu, T. (2009). İlköğretim okulu müdürlerinin liderlik rolleri. Kuram ve Uygulamada Eğitim Yönetimi, 15(58), 274-298.

Tepe, H. (2000). Etik ve meslek etikleri: Tip, çevre, iş, basın, hukuk. Türkiye Felsefe Kurumu Yayınları.

Tims, M., Bakker, A. B., \& Xanthopoulou, D. (2011). Do transformational leaders enhance their followers' daily work engagement? The Leadership Quarterly, 22, 121-131. 
Toor, S.-u.-R., Ofori, G. (2009). Ethical leadership: Examining the relationships with full range leadership model, employee outcomes, and organizational culture. Journal of Business Ethics, 90, 533-547. doi:10.1007/s10551-009-0059-3

Tosun, F. (2015). Okul yöneticilerinin dönüşümcü liderlik özelliklerinin öğretmen görüşlerine göre araştırılması (Yayımlanmamış yüksek lisans tezi). İstanbul Aydın Üniversitesi, Sosyal Bilimler Enstitüsü, İstanbul.

Treviño, L. K., Brown, M., \& Hartman, L. P. (2003). A qualitative investigation of perceived executive ethical leadership: Perceptions from inside and outside the executive suite. Human Relations, 55, 5-37. doi: $10.1177 / 0018726703056001448$

Tschannen-Moran M and Woolfolk Hoy A (2007) The differential antecedents of selfefficacy beliefs of novice and experienced teachers. Teaching and Teacher Education 23, 944-956.

Uğurluoğlu, Ö. \& Çelik, Y. (2009). Örgütlerde stratejik liderlik ve özellikleri. Hacettepe Sağlık ̇̇aresi Dergisi, $12(2), 121-156$.

Van Wart, M. (2014). Contemporary varieties of ethical leadership in organizations. International Journal of Business Administration, 5(5), 27. doi:10.5430/ijba.v5n5p27

Vugt, M. V., Jepson, S. F., Hart, C. M. ve Cremer, D. (2004). Autocratic leadership in socialdilemmas: A threatto group stability. Journal of Experimental Social Psychology, 40(1), 1-13.

Wang, G., Oh, I., Courtright, S., \& Colbert, A. (2011). Transformational leadership and performance across criteria and levels: A meta-analytic review of 25 years of research. Group \& Organization Management, $36,223-270$.

Waters, T., Marzano, R. J., \& McNulty, B. (2003). Balanced leadership: What 30 years of research tells us about the effect of leadership on student achievement. Aurora, CO: Mid-Continent Research for Education and Learning.

Westwood, R. (1997). Harmony and patriarchy: The cultural basis for paternalistic headship among the overseas Chinese. Organization Studies, 18(3), 445-480.

Woods, G. (2007). The 'bigger feeling': the importance of spiritual experience in educational leadership. Educational Management Administration \& Leadership, 35(1), 135-55.

Wu, M., Huang, X., Li, C., Liu, W. (2011). Perceived interactional justice and trust-in-supervisor as mediators for paternalistic leadership. Management and Organization Review, 8, 97-121.

Yılmaz, E. (2010). Ilköğretim okulu müdürlerinin öğretimsel liderlik rolleri ile etkili okul arasındaki ilişkinin değerlendirilmesi (Yayımlanmamış yüksek lisans tezi). Gazi Üniversitesi, Ankara.

Zengin, M. (2019). Ortaöğretim ögretmenlerinin algllarına göre okul müdürlerinin dönüşümcü liderlik özellikleri ile okul güvenliği ve örgütsel imaj arasındaki ilişki (Yayımlanmamış doktora tezi). Atatürk Üniversitesi, Erzurum. 
F.Ü. Sosyal Bilimler Dergisi 2021-31/3 